\title{
PRECIPITATING AUTO-ANTIBODIES IN THE CONNECTIVE TISSUE DISEASES
}

\author{
BY \\ J. R. ANDERSON, K. G. GRAY, J. S. BECK, W. W. BUCHANAN, \\ AND A. J. MCELHINNEY \\ From the University Departments of Pathology and Medicine at the Western Infirmary, Glasgow
}

In a recent communication we described the occurrence in the serum of patients with Sjögren's disease of two factors which reacted to give precipitates with extracts of various tissues. Evidence was provided that both factors were auto-antibodies (Anderson, Gray, Beck, and Kinnear, 1961b). As Sjögren's disease has close associations with the connective tissue diseases (Heaton, 1959; Bunim, 1961), we thought it of interest to see if autoprecipitins could be detected in patients with connective tissue diseases. This paper describes the detection, in the serum of patients with various connective tissue diseases, of the two auto-antibodies which occur in Sjögren's disease and two additional precipitating antibodies, one of which is an autoantibody to deoxyribonucleic acid.

\section{Material and Methods}

As most of the methods used have been described in the previous communication (Anderson and others, $1961 \mathrm{~b})$, only a brief outline of these is necessary.

Precipitin Tests upon serum were performed by an Ouchterlony agar-diffusion technique, $0 \cdot 1$ per cent. of sodium azide being incorporated in the agar to control contamination. As strongly-reacting serum required to be diluted to demonstrate its reaction satisfactorily by this method, all specimens were tested undiluted and at a dilution of 1 in 8 . Positive sera were titrated in 2-fold or 4-fold dilutions. The antigens consisted of 50 per cent. buffer-saline extracts of human tissues of normal naked-eye appearance, obtained within a few hours after death, from patients dying of various unselected conditions. Extracts were also prepared from animal tissues and from surgically-removed human tissues. Human thyroid tissue was used routinely as the antigen for precipitin tests and positive sera were tested also with extracts of other tissues, usually the spleen and submandibular gland.

Comparison of the Antibodies in positive specimens of serum was made by direct tests for identity, using the
Ouchterlony technique, and also by antigen-annulment $\stackrel{\sim}{\rightarrow}$ tests in which the serum was tested with specimens of tissue extracts which had been selectively annulled by $\omega^{\prime}$ treatment with other positive sera: a negative result indicated that the test-serum and serum effecting annul- 음 ment contained the same antibody. The nature of the serum factors responsible for precipitation was investigated by immuno-electrophoresis in agar-gel and by ultracentrifugation.

Complement-Fixation $(C-F)$ Tests were performed with $\stackrel{\mathbb{D}}{-}$ dilutions of test serum, using constant amounts of conge $\vec{\theta}$ plement and antigen (tissue extract).

Fluorescent Antibody Tests were carried out by "sandwich" technique, using unfixed cryostat sections of animal (usually rat) liver, and a fluorescein-labelled rabbit anti-human- $\gamma$-globulin serum as described by Beck (1961).

Highly polymerized deoxyribonucleic acid (DNA) from calf thymus and also deoxyribonuclease (DNase), $\overrightarrow{\hat{O}}$ ribonuclease (RNase), and soy-bean trypsin inhibitor 3 were obtained from the Nutritional Biochemical Corporation. Human deoxyribonucleoprotein (DNP) and DNA were prepared from spleen; DNP by the methods of Crampton, Lipshitz, and Chargaff (1954) using solutions of low ionic strength, and of Mirsky and Pollister (1946) using solutions of high ionic strength; DNA by the method of Kay, Simmons, and Dounce (1952). Calfthymus DNA was also prepared by this last method, 3 and was further purified by treatment with chloroform, followed by treatment with RNase and dialysis against $0 \cdot 15 \mathrm{M}$ saline. Before use as antigen in Ouchterlony $D$ precipitin tests, DNA solutions were treated for $10 \mathrm{~min}$. 을 at $0-5^{\circ} \mathrm{C}$. under an atmosphere of hydrogen, in a Mullard $\vec{N}$ ultrasonic disintegrator.

The effect of enzymes on the antigens was investigated $\mathrm{N}$ by incubating tissue extracts with a solution of the enzyme N్ for $1 \mathrm{hr}$ at $37^{\circ} \mathrm{C}$. DNase and RNase were dissolved in phosphate buffer-saline of $\mathrm{pH} 6.8$ containing $0.005 \mathrm{M}$ $\mathrm{MgCl}_{2}$. Crystalline trypsin (Armour) was dissolved in phosphate buffer-saline at $\mathrm{pH} 7 \cdot 4$, and was added to the extracts to give a concentration of $1 \mathrm{mg} . / \mathrm{ml} .:$ after ${ }^{\infty}$ incubation, soy-bean trypsin-inhibitor was added. 
Sera Tested.-Precipitin tests were performed on the serum of 541 hospital patients, including 188 with connective tissue diseases (Table I) and 353 with various other conditions who acted as controls. The group with connective tissue diseases included 37 patients with "Sjögren's disease". Most of these had keratoconjunctivitis sicca, with or without the additional features of Sjögren's syndrome; a few had Mikulicz's disease without clinical evidence of keratoconjunctivitis sicca. Investigations on the serum of 29 of the patients with Sjögren's disease were described in the previous communication. Serum was obtained from fourteen of the 28 patients with systemic lupus erythematosus (S.L.E.)' while the disease process was in an active stage, either before, or within a few days after, the commencement of therapy: the remaining fourteen specimens were from patients who had received treatment for longer periods. The criteria applied in the diagnosis of the connective tissue diseases have been stated elsewhere (Anderson, Goudie, Gray, and Buchanan, 1961a).

The "control" group of patients included:

(a) 96 with certain diseases in which auto-immune reactions with tissue constituents have been either described or suggested : the diseases comprising this group are given in Table II;

(b) 236 patients with various surgical, gynaecological, or medical conditions;

(c) 21 patients with lesions of the salivary glands or eyes other than Sjögren's disease (e.g. acute bacterial parotitis, sialolithiasis, mumps, salivary gland tumours, orbital pseudotumour).

Control groups $(b)$ and $(c)$ are recorded together as "various other conditions" in Table II.

\section{Results}

Precipitin Test.-This was positive with the serum of 57 patients with connective tissue diseases, and with eight of the control specimens (Tables I and II).
TABLE II

RESULTS OF PRECIPITIN TESTS, AND TYPES OF ANTIBODY, IN “CONTROL” PATIENTS

\begin{tabular}{|c|c|c|c|c|c|}
\hline \multicolumn{3}{|l|}{ Diagnosis } & $\begin{array}{l}\text { No. of } \\
\text { Patients }\end{array}$ & $\begin{array}{l}\text { No. } \\
\text { Positive }\end{array}$ & $\begin{array}{l}\text { Type of } \\
\text { Antibody }\end{array}$ \\
\hline $\begin{array}{l}\text { Cirrhosis . } \\
\text { Mitral stenosis } \quad \ldots \\
\text { Auto-immune haemol }\end{array}$ & $\ddot{x}$ & $\cdots$ & $\begin{array}{l}18 \\
16\end{array}$ & $\begin{array}{l}1^{*} \\
0\end{array}$ & N.I. \\
\hline anaemia & . & $\ldots$ & 12 & 0 & - \\
\hline Multiple sclerosis & . & $\ldots$ & 10 & 0 & - \\
\hline Hashimoto's disease & . & $\ldots$ & 9 & 2 & N.I. \\
\hline Myasthenia gravis & . & $\cdots$ & 7 & 0 & - \\
\hline Syphilis . . $\ldots$ & . & $\ldots$ & 6 & 0 & - \\
\hline Sarcoidosis $\quad \ldots$ & . & $\ldots$ & 5 & 1 & N.I. \\
\hline Ulcerative colitis .. & . & $\ldots$ & 5 & 0 & - \\
\hline Addison's disease & . & $\ldots$ & 4 & 0 & - \\
\hline "Paraglobulinaemia" & . & $\cdots$ & 2 & 2 & Both \\
\hline $\begin{array}{l}\text { Thrombocytopenic pu } \\
\text { Various other conditi }\end{array}$ & sura & $\begin{array}{l}\cdots \\
\cdots\end{array}$ & $\begin{array}{r}2 \\
257\end{array}$ & $\begin{array}{l}\mathbf{0} \\
\mathbf{2}\end{array}$ & N.I. \\
\hline
\end{tabular}

N.I. = Not identified.

* This patient also had primary hypothyroidism

The precipitating titres of positive specimens ranged from 1 to 1 in 512: with two exceptions, titres of 1 in 64 or more were confined to the patients with connective tissue diseases. Many of the positive specimens gave a single line of precipitate, some gave two lines, and a few three lines. Difficulties encountered in reading the precipitin tests were due mainly to a halo of opacity developing in the agar around the tissue-extract well, and to faint slowly-developing precipitates, which occurred inconstantly with certain dilutions of some specimens of normal and test serum. These effects, which are not regarded as indicative of precipitin reactions, have been discussed in the previous communication, and were taken into consideration in reading the results in the present investigation. A further difficulty, which was encountered when thyroid tissue extract was used as antigen, was due to the presence of precipitating antithyroglobulin in some of the sera. The resulting precipitate was readily identified, as thyroglobulin was present in relative

TABLE I

RESULTS OF PRECIPITIN TESTS AND TYPES OF ANTIBODY FOUND IN PATIENTS WITH CONNECTIVE TISSUE DISEASES

\begin{tabular}{|c|c|c|c|c|c|c|c|c|c|}
\hline \multirow{2}{*}{\multicolumn{3}{|c|}{ Diagnosis }} & \multirow{2}{*}{$\begin{array}{c}\text { No. } \\
\text { of } \\
\text { Patients }\end{array}$} & \multirow{2}{*}{$\stackrel{\text { No. }}{\text { Positive }}$} & \multicolumn{5}{|c|}{ No. with Anti- } \\
\hline & & & & & $\mathbf{S j D}$ & $\mathrm{SjT}$ & DNA & Lup & NI* \\
\hline $\begin{array}{l}\text { Systemic lupus erythematosus } \\
\text { Discoid lupus erythematosus } \\
\text { Sjögren's disease . } \\
\text { Rheumatoid arthritis } \quad . \\
\text { Progressive systemic sclerosis } \\
\text { Dermatomyositis .. } \\
\text { "Lupoid" hepatitis } \\
\text { "Lolyarteritis nodosa }\end{array}$ & $\begin{array}{l}\ldots \\
\cdots \\
\cdots \\
\ldots \\
\cdots \\
\cdots\end{array}$ & $\begin{array}{l}\cdots \\
\cdots \\
\cdots \\
\cdots \\
\cdots \\
\cdots\end{array}$ & $\begin{array}{r}28 \\
16 \\
37 \\
90 \\
10 \\
3 \\
1 \\
3\end{array}$ & $\begin{array}{r}21 \\
2 \\
13 \\
13 \\
5 \\
2 \\
1 \\
0\end{array}$ & $\begin{array}{l}6 \\
\mathbf{1} \\
\mathbf{7} \\
\mathbf{3} \\
\mathbf{3} \\
\mathbf{0} \\
\mathbf{1} \\
\mathbf{0}\end{array}$ & $\begin{array}{l}1 \\
0 \\
5 \\
1 \\
0 \\
0 \\
0\end{array}$ & $\begin{array}{l}\mathbf{3} \\
\mathbf{0} \\
\mathbf{0} \\
\mathbf{0} \\
\mathbf{0} \\
\mathbf{0} \\
\mathbf{0} \\
\mathbf{0}\end{array}$ & $\begin{array}{l}\mathbf{7} \\
\mathbf{0} \\
\mathbf{0} \\
\mathbf{0} \\
\mathbf{2} \\
\mathbf{0} \\
\mathbf{0} \\
\mathbf{0}\end{array}$ & $\begin{array}{r}7 \\
1 \\
5 \\
11 \\
1 \\
2 \\
0 \\
0\end{array}$ \\
\hline
\end{tabular}

* NI = Antibody not identified. 
excess, and the precipitate developed as a broad zone which migrated towards the serum-well as the zone of antigen excess extended towards this well. Precipitating antithyroglobulin was identified also by precipitin tests using purified thyroglobulin as antigen, and by its failure to react with extracts of tissues other than thyroid. Precipitin reactions attributable to antithyroglobulin are excluded from the tables of results.

Comparison of the Positive Specimens of Serum.This was made by direct Ouchterlony tests for identity, and by antigen-annulment tests, and demonstrated the occurrence of several independent precipitating factors. In general, the results with these two tests were in agreement, although the antigen-annulment tests were found to be more useful and reliable, because direct tests of identity were influenced by antigen-antibody proportions and were sometimes difficult to interpret, particularly when applied to weakly-reacting serum. Of the various serum factors demonstrated, four were investigated more fully. Direct identity tests, an example of which is shown in Fig. 1, and antigenannulment tests (Table III) showed these four factors to react with different constituents of tissue extracts. Two of the factors (anti-SjD and anti-SjT) are those already described in Sjögren's disease (Anderson and others, 1961b). Their differentiation is facilitated by the use of suitably selected tissue extracts, for some extracts, after admixture with serum containing anti-SjT, fail to react with both anti-SjT and anti-SjD sera, suggesting that, in such extracts, the factor $\mathrm{SjD}$ may be in combination with $\mathrm{SjT}$. In other extracts, the tissue factors $\mathrm{SjD}$ and SjT behaved independently, as shown in Table III. Evidence is presented below that the third serum factor is an antibody to DNA, while the fourth factor, which was first detected in the serum of a patient with S.L.E. has been termed, for convenience, anti-Lup. 42 examples of the four serum factors were detected among the positive serum specimens

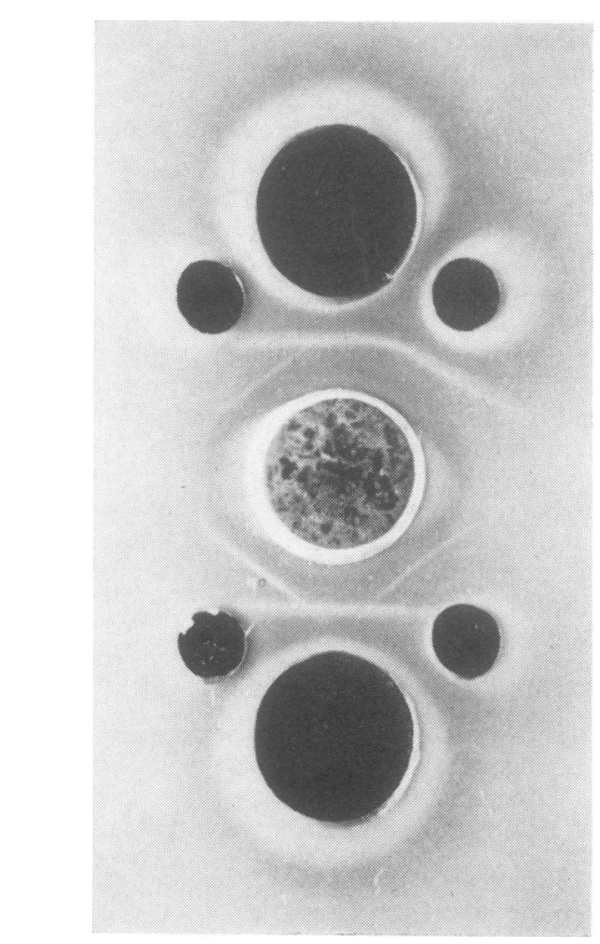

Fig. 1.-Direct identity tests between serum containing anti-D (upper and lower large wells) and four positive sera (small wejs) Central well contains thyroid tissue extract. Only the upper righto serum, which contains anti-DNA, shows a "reaction of identity' (complete fusion of precipitates). The other three sera contain anti-Lup (upper left), anti-SjT (lower left), and anti-SjD (lower right) and show "reactions of non-identity" (crossing of precipitates).

(Tables I and II). Precipitin reactions with serao containing examples of the four factors are shown 3 in Fig. 2 (opposite).

Some of the other precipitating factors were too. weak for identification; others were shown to beo different from the above four factors, but have not been further investigated. Specimens of serum 3 giving more than one line of precipitate could usually'

TABLE III

ANTIGEN-ANNULMENT PRECIPITIN TESTS SHOWING FOUR DIFFERENT SERUM FACTORS

\begin{tabular}{|c|c|c|c|c|c|c|}
\hline \multirow{2}{*}{$\begin{array}{l}\text { Tissue Extract } \\
\text { Annulled with } \\
\text { Serum }\end{array}$} & \multicolumn{5}{|c|}{ Treated Tissue Extract tested with Serum } & \multirow{2}{*}{$\begin{array}{l}\text { Serum } \\
\text { Factor } \\
\text { Present }\end{array}$} \\
\hline & Don & Tra & McDou & Dun & Normal Serum & \\
\hline Don & - & + & + & + & - & Anti-SjD \\
\hline Tra & + & - & + & + & - & Anti-SjT \\
\hline McDou & + & + & - & + & - & Anti-DNA \\
\hline Dun & + & + & + & - & - & Anti-Lup \\
\hline Normal Serum & + & + & + & + & - & Nil \\
\hline
\end{tabular}




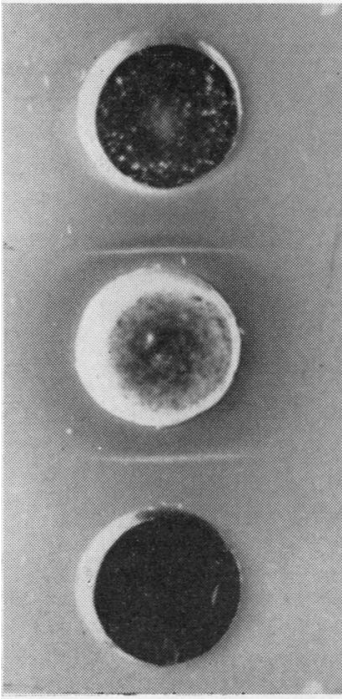

(a)

Anti-SjT

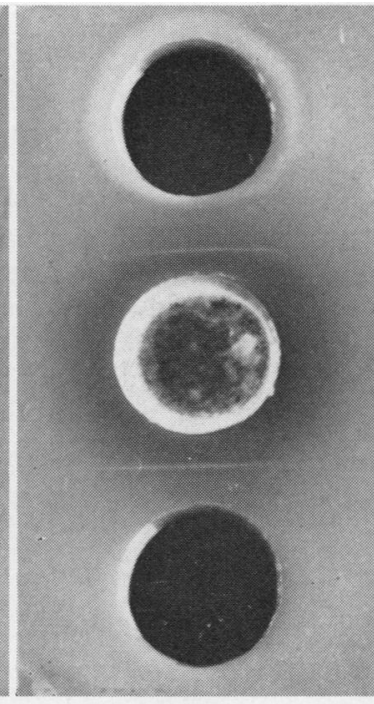

(b)

Anti-SjD

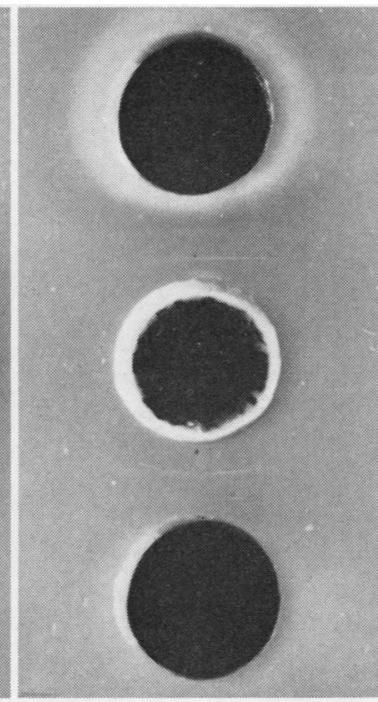

(c)

Anti-Lup

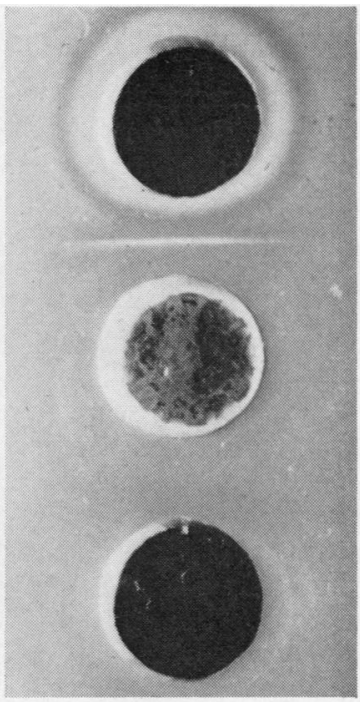

(d)

Anti-DNA

Fig. 2.-Precipitin tests, Upper wells contain undiluted serum, lower wells serum diluted 1 in 8 . Centre wells contain thyroid tissue extract. All except the anti-DNA serum react at both dilutions.

be demonstrated to contain more than one precipitating factor, but some specimens which, judging by direct identity tests and antigen-annulment tests, contained only one of the four factors, gave, at certain dilutions, two lines of precipitate.

Nature of the Serum Precipitating Factors.-The four serum factors were observed on immunoelectrophoresis to have the characteristic mobility of $\gamma$-globulin, and three of them (anti-SjD, anti-SjT, and anti-Lup) were examined by ultracentrifugation and found to have a sedimentation coefficient of $7 \mathrm{~S}$. From these results we consider it most likely that the four serum factors are antibodies.

Auto-immune Nature of the Antibodies.-This is supported by two pieces of evidence.

First, each of the four types of antibody was tested with tissue extracts from at least forty individuals. With one exception, the corresponding antigens were detected in the tissues of all individuals tested, although it was sometimes necessary to concentrate a tissue extract (by freeze-drying) to detect a particular antigen in it. The single exception was a negative result when tissue extracts from a patient with progressive systemic sclerosis were tested with anti-SjD serum. It was subsequently shown that the tissue extracts of this individual contained free anti-SjD, and the negative result is readily explained by annulment of the antigen $\mathrm{SjD}$ by autologous antibody. These results suggest that the antigens are present in the tissues of all individuals, and therefore that the antibodies are of an auto-immune nature.

The second, stronger, piece of evidence in favour of auto-immunization, applies to three of the antibodies. Two patients whose serum contained precipitating antibodies died, and extracts of their tissues were shown to contain the corresponding antigens. One was a patient with rheumatoid arthritis, whose serum contained low titres of antiSjD and anti-SjT: the tissue extracts reacted with the patient's own serum, and with other sera containing anti-SjD or anti-SjT. The other was a patient with S.L.E., whose serum contained antiDNA; both crude tissue extracts and splenic DNA were found to react with the patient's own serum, and with the other examples of anti-DNA serum. Opportunity has not arisen to test the tissue extracts of any patient whose serum contained anti-Lup.

Features of the Antigens.-Evidence that one of the antigens is DNA is presented below. The three other antigens have not been identified. Some of the features of the antigens $\mathrm{SjD}$ and $\mathrm{SjT}$ were described in the previous communication and need not be given in detail here. All four antigens were detected in extracts of human thyroid, salivary glands, liver, kidney, spleen, and adrenal: none of them was detected in extracts of red cells or platelets, nor in serum, plasma, or $\gamma$-globulin. Extracts of leucocytes isolated from normal blood and from 
the blood of patients with chronic myeloid leukaemia reacted with anti-DNA serum only; mixtures of these extracts with tissue extract did not react to give precipitates with the other three antibodies, and it may be that extracts of myeloid leucocytes contain factors, possibly enzymes, which destroy the antigens $\mathrm{SjD}, \mathrm{SjT}$, and Lup. Extracts of leucocytes from patients with chronic lymphatic leukaemia reacted with all four antibodies.

Some other features of the antigens are summarized in Table IV. The animal tissue extracts were prepared from spleen, liver, and kidney: tests with these extracts were complicated by the development of dense haloes of opacity in the agar around the tissue-extract wells, particularly with liver extracts, which were capable of obscuring any faint precipitin reactions occurring within the zone of opacity. Thus it is possible that the negative results with some of the animal tissue extracts are due to quantitative rather than qualitative interspecies antigenic differences. Ouchterlony tests of antigenidentity upon positive tissue extracts failed to show variations in the antigenicity of any one of the four antigens as it occurred in extracts of different tissues and in the tissues of different individuals and animal species. Preparations of histone and of the phosphate-buffer-extractable nuclear antigen described by Holman, Deicher, and Kunkel (1959) and by Lachmann and Kunkel (1961) did not react to give precipitation with any of the four antibodies.

\section{EVIDENCE that ONe of the ANTigens is DNA}

The three specimens of anti-DNA serum reacted with crude tissue extracts, human DNP, and human and calf-thymus DNA preparations: all of these tissue preparations failed to react after treatment with DNase, and were unaffected by treatment with RNase or trypsin, and by heating for $1 \mathrm{hr}$ at $75^{\circ} \mathrm{C}$. The antibody present in these specimens of serum was annulled by treatment at $4^{\circ} \mathrm{C}$. overnight with
DNP or with human or calf-thymus DNA in a concentration of $25 \mu \mathrm{g} . / \mathrm{ml}$. The highly purified 3

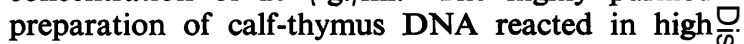
dilution $(1.5 \mu \mathrm{g} . / \mathrm{ml}$.) to give a precipitate. While: it was necessary to treat solutions of DNA by $\overrightarrow{\overrightarrow{\vec{S}}}$ ultrasonic vibration to provide a satisfactory antigeno for agar-diffusion precipitin tests, the effect of such treatment was merely to render the DNA more $\overline{\bar{c}}$. readily diffusible in agar, and did not appear to alter its antigenicity, for untreated DNA was shown to be capable of annulling the antibody, and did, in fact, ${ }^{\infty}$ react in agar-diffusion precipitin tests, although the. precipitate developed very close to the edge of the $\overrightarrow{\vec{\omega}}$ antigen well. The polyanionic compound, poly-L- $-\omega$ glutamic acid, neither reacted with nor annulled the antibody. None of the other three antigenantibody systems was influenced by treatment of the antibody serum with DNA or DNP, or the tissue extract with DNase.

The fourth antigen, Lup, may be wholly or partlyo of protein nature, for it was weakened by treatment ${ }_{-}^{-}$ with trypsin and was destroyed by heating at $55^{\circ} \mathrm{C}$. $\vec{\square}$ It was detected in crude preparations of DNP, but ${ }^{\Phi}$ not in DNP which had been purified by repeated ${ }^{\mathbb{\Phi}}$ precipitation in $0.15 \mathrm{M}$ saline. Fluorescent-anti-ठ body studies with serum containing anti-Lup ${ }^{\stackrel{D}{~}}$ invariably showed nuclear fluorescence, but the $\vec{\theta}$ type of staining varied with individual sera, being "homogeneous" with some and "speckled" wion others. These different appearances have been described by Beck (1961); there is no good evidence that either of them is attributable to anti-Lup.

Precipitin Tests with DNP.-There is evidence $\frac{}{\Phi}$ that the serum of patients with active S.L.E. $\overrightarrow{\vec{F}}$ commonly contain antibody to DNP which does not react with DNA alone. This was described by? Holman and Deicher (1959), using a C-F technique and L.E. cell tests, and by Holborow and Weir (1959), using a fluorescent-antibody technique. Accordingly, precipitin tests were performed upono S.L.E. sera, using as antigens the two preparations

TABLE IV

SOME PROPERTIES OF THE FOUR TISSUE ANTIGENS

\begin{tabular}{|c|c|c|c|c|c|c|}
\hline \multirow{2}{*}{\multicolumn{3}{|c|}{ Property }} & \multicolumn{4}{|c|}{ Antigens } \\
\hline & & & SjD & SjT & DNA & Lup \\
\hline Destroyed by heating for $1 \mathrm{hr}$ at & . $\quad \ldots$ & $\cdots$ & $65^{\circ} \mathrm{C}$ & $55^{\circ} \mathrm{C}$ & $100^{\circ} \mathrm{C}$ & $55^{\circ} \mathrm{C}$ \\
\hline Destroyed by & $\begin{array}{l}\text { Trypsin } \\
\text { DNase } \\
\text { RNase } \\
\text { W.B.C. Extracts }\end{array}$ & & $\begin{array}{l}\text { No } \\
\text { No } \\
\text { No } \\
\text { Yes }\end{array}$ & $\begin{array}{l}\text { Yes } \\
\text { No } \\
\text { No } \\
\text { Yes }\end{array}$ & $\begin{array}{l}\text { No } \\
\text { Yes } \\
\text { No } \\
\text { No }\end{array}$ & $\begin{array}{c}\text { Weakened } \\
\text { No } \\
\text { No } \\
\text { Yes }\end{array}$ \\
\hline Present in Tissues of & $\cdots$ & $\cdots$ & G. & R., G., M. & R., G., Rat, M. & R., G., Rat, M \\
\hline
\end{tabular}

R., G., Rat, M. = rabbit, guinea-pig, rat, mouse, respectively. 
of human DNP. These tests were carried out, as usual, in agar dissolved in $0.15 \mathrm{M}$ saline but, as DNP is highly insoluble in $0 \cdot 15 \mathrm{M}$ saline, they were repeated in agar dissolved in distilled water, and in $1.0 \mathrm{M}$ saline. Tests were also performed with DNP subjected to ultrasonic vibration. Precipitin reactions attributable to anti-DNP did not occur, but sera containing anti-DNA reacted to give precipitation in all tests performed in agar dissolved in water and in $0.15 \mathrm{M}$ saline, but not in $1.0 \mathrm{M}$ saline. These reactions were inhibited by pretreating the serum with DNA, and are not indicative of antibody reacting specifically with DNP. The negative results in $1.0 \mathrm{M}$ saline-agar are in agreement with the observations of Seligmann (1958) and of Deicher, Holman, and Kunkel (1959) that high salt concentrations inhibited precipitation of DNAantibody complex. The other three precipitating systems investigated were less affected by salt concentration, for they were demonstrable in tests with crude tissue extracts performed in agar dissolved in $1.0 \mathrm{M}$ saline.

Complement-Fixation Tests.-These were performed upon some of the specimens of serum of patients with connective tissue diseases. Specimens containing anti-SjT invariably reacted to fix complement, and the titres were, in general, parallel to the precipitin titres. Some specimens containing anti$\mathrm{SjD}$ gave negative $\mathrm{C}-\mathrm{F}$ tests, while anti-Lup sera were positive, but the titres did not parallel the precipitin titres. The specimens of serum containing anti-DNA were strongly anticomplementary, and could be tested only at dilutions of 1 in 16 or higher, at which the C-F tests were negative. Some of the precipitin-negative specimens of serum gave positive C-F tests, occasionally in high dilutions, and it is clear that this method of testing demonstrates serum factors not detected by the precipitin tests.

Incidence and Titres of the Antibodies.-The number of patients investigated was too small to give an accurate indication of the incidence of the antibodies in the different connective tissue diseases, and furthermore, many of the serum factors which were too weak to classify doubtless include examples of the antibodies described. It is clear from Table I, however, that the highest incidences of the antibodies were observed in S.L.E., in which all four types were found, and in Sjögren's disease, in which only anti-SjD and anti-SjT were recognized. The highest titres of antibody also occurred in Sjögren's disease and S.L.E. Several specimens had an anti-SjT titre of 1 in 256, and one reacted at 1 in 512.
Anti-SjD and anti-Lup both occurred in titres up to 1 in 64 , while the three specimens of anti-DNA had titres of 1 in 4 to 1 in 8 . None of the four antibodies was invariably present in L.E. cell-positive sera, and in three such specimens the precipitin test was negative. Thirteen of the fourteen specimens obtained from patients with S.L.E. before or shortly after starting treatment gave a positive precipitin test, while later specimens showed a distinct tendency for the antibodies, particularly anti-DNA and anti-Lup, to diminish or disappear during clinical remissions and to increase or reappear during exacerbations. Multiple serum specimens from patients with connective tissue diseases other than S.L.E. showed little variation in their precipitin reactions over periods up to 18 months.

Positive Control Specimens.-Only two of the eight positive control specimens (Table II) gave strong enough precipitin reactions for their serum factors to be identified. These two specimens were from patients classified as having "paraglobulinaemia": they contained anti-SjT in titres of 1 in 128 and 1 in 256 . One patient, a woman of 56, had the characteristic features of Waldenström's macroglobulinaemia. The other, a man of 70 , had congestive heart failure, a serum globulin level of $4 \cdot 1 \mathrm{~g} .100 \mathrm{ml}$, , and a serum electrophoretic $\gamma$ globulin peak suggestive of myelomatosis. His liver was enlarged and firm, tests for Bence-Jones protein were negative, and biopsy of the sternal marrow showed an increase in plasma cells, but was not considered diagnostic of myelomatosis.

The two positive control specimens in the group with "various other conditions" were both from patients with aplastic anaemia, and both have since died. Post mortem examination of one of them showed no evidence of connective tissue diseases apart from "onion-skin" fibrosis around occasional arterioles in the spleen. This pathological change is suggestive, but probably not diagnostic, of S.L.E. (Kaiser, 1942). Three of the positive control specimens were from patients with severe chronic thyroiditis; two of these had Hashimoto's disease, one without any unusual clinical features and the other with hepato-splenomegaly and hypoplastic anaemia. Needle biopsy of the liver showed no evidence of cirrhosis. The third patient had primary hypothyroidism and a firm enlarged nodular liver with portal hypertension; liver biopsy was not performed and the diagnosis of cirrhosis was not confirmed. The last positive control serum was from a patient with sarcoidosis, confirmed by a positive Kveim test and biopsy of the parotid gland, and showing no evidence of a connective tissue disease. 


\section{Discussion}

This investigation demonstrates the occurrence, among patients with connective tissue diseases and certain other conditions, of serum factors which react with tissue extracts to produce precipitation in agar-diffusion tests. In view of the complex nature of the test reagents, many possible interpretations could be advanced to explain the precipitates. However, four of the serum factors were investigated and were shown to have the electrophoretic properties of $\gamma$-globulin, and three of them were shown to have a sedimentation coefficient of $7 \mathrm{~S}$. These four serum factors were also shown to react independently with different constituents of tissue extracts, and in this respect exhibited the specificity of antibodies. Further evidence of the antibody nature of one of the factors, anti-SjT, was provided in the previous communication (Anderson and others, 1961b).

Auto-immune Nature of the Antibodies.-This is more difficult to establish. Perhaps the only acceptable evidence for the auto-immune nature of an antibody is the demonstration that it reacts specifically with a normal body constituent present in the individual who has developed the antibody; such evidence is always open to the criticism that the patient's tissues may be abnormal and that the antibody may react with an abnormal substance produced in vivo by a metabolic disturbance or by formation of a complex with an exogenous agent, and in vitro by the manipulations involved in preparing the antigenic test reagent. The demonstration of such abnormal antigenic substances would not only shed light on the nature of the underlying disturbances, but would also have important implications on the nature of autoimmunity. An example is provided by Sedormidinduced purpura, in which the antigenicity of the platelets is altered by union with Sedormid (Ackroyd, 1955). It seems unlikely that metabolic disturbances or union with exogenous agents are important in the auto-immune phenomena of the connective tissue diseases, for one of the features of these phenomena is the wide variety of body constituents to which antibodies may develop. A disturbance of the immunity mechanism, with development of antibodies to normal endogenous substances, seems a more likely explanation. Accordingly, we regard the evidence in favour of the auto-immune nature of three of the antibodies-anti-SjD, anti-SjT, and anti-DNA - to be strong: the antigens $\mathrm{SjD}$ and $\mathrm{SjT}$ were detected in extracts of the tissues of a patient whose serum contained both the antibodies, while anti-DNA serum reacted with preparations of the

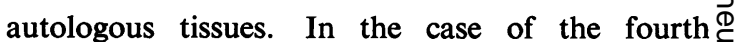
antibody, anti-Lup, evidence of auto-immunity is 3

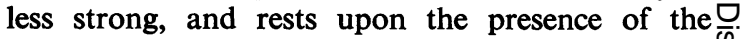
corresponding antigen in the tissues of all individuals? tested. The importance of providing strong evidence of the auto-immune nature of the precipitating antibodies described is emphasized by the detection, in a current investigation, of isoprecipitins reacting with extracts of tissues and developing apparently $\vec{\varnothing}$ from the antigenic stimulation provided by administration of leucocytes in transfused blood.

The occasional development of two lines of $\overrightarrow{0}$ precipitate in precipitin tests with serum considered $\overrightarrow{\vec{\omega}}$ to contain only one of the four types of antibody, $\omega$ does not indicate that more than one antigenantibody reaction is concerned, as similar results have been described with single antigen-antibody systems by Korngold and van Leeuwen (1959).

Evidence for Antibody to DNA.-Of the variousO auto-antibodies which occur in the serum of patientso with S.L.E., those which react with constituents of cell nuclei have aroused considerable interest. Among them antibody to DNA has been described by several groups of workers, by methods employing complement-fixation (Ceppellini, Polli, and Celada, 1957; Pearson, Craddock, and Simmons, 1958; Robbins, Holman, Deicher, and Kunkel, 19:9 Seligmann, 1957), precipitation (Ceppellini as d others, 1957; Seligmann, 1957; Deicher and othés. 1959), haemagglutination (Miescher and Strässte, s 1957), and by passive cutaneous anaphylaxiso (Deicher, Holman, Kunkel, and Ovary, 1960) Evidence that the precipitin reaction with DNA is of an immunological nature, and that DNA, and not an impurity, is the antigen concerned, is welf presented by Seligmann (1958), and our own findingsare in complete agreement in showing that veryo dilute solutions of DNA, prepared from various species, are antigenic, that the antigen is destroyec $\bar{E}$ by DNase, unaffected by RNase, trypsin, and by heating at $75^{\circ} \mathrm{C}$., and does not readily diffuse in agar unless pretreated with ultrasonic vibrationô The antibody was inhibited by treatment with DNP or DNA. Since DNA is active in high dilutions in the precipitin test, it is not surprising that theres should be enough present in crude tissue extracts. and preparations of DNP to give a positive reaction The DNA in these preparations differed fron ${ }^{r}$ purified DNA in being more readily diffusible in agar, and gave a satisfactory precipitate without pretreatment by ultrasonic vibration.

The occurrence, in the serum of patients with S.L.E. of precipitating antibody reacting with constituent of leucocytes other than DNA is des? cribed by Seligmann (1958), but it is unlikely thato 
it is one of the other three antibodies described above, for these did not react with extracts of leucocytes from normal blood, but only with extracts of lymphatic leukaemic leucocytes or of tissues.

Relation of Serum Precipitins to the "AICF" Reaction.-Complement-fixation tests upon some of our sera demonstrated the presence of complement-fixing serum factors not detected by precipitin tests, and also suggested that anti-SjT and anti-Lup are capable of fixing complement. Since the corresponding antigens are present in human and animal tissues, it may be that these two antibodies participate in the "auto-immune complement-fixation" (AICF) reaction described by Gajdusek and his co-workers (Gajdusek, 1957, 1958; Mackay and Gajdusek, 1958) and by Hackett, Beech, and Forbes (1960). In this reaction, the serum of patients with certain types of disease was shown to fix complement when incubated with crude saline extracts of various human and animal tissues. Positive results occurred with a small proportion of patients with diverse common conditions, but the incidence was increased, and higher serum titres were observed, in patients with connective tissue diseases, certain types of liver disease, and "paraglobulinaemias" - the same conditions in which we have observed most of the precipitin reactions in this investigation. Asherson (1959), and Deicher, Holman, and Kunkel (1960) performed C-F tests with the serum of patients with these conditions, using as antigens various cellular constituents prepared by differential centrifugation of homogenized human and animal tissues; they encountered a multiplicity of C-F systems and their results provide strong evidence that both nuclear and cytoplasmic cell constituents are concerned in the reactions.

Failures to Demonstrate Autologous Reactions.There is some doubt about whether auto-antibodies or isoantibodies are concerned in the AICF reaction, for Mackay and Larkin (1959) obtained irregular results in tests of positive serum specimens with autologous tissue extracts. In some cases the autologous reaction was positive, while in othersusually when the serum titre was high-it was negative, although all the tissue extracts reacted with positive serum from other individuals. Failure to demonstrate the autologous reaction between serum and tissue extract, both of which participated in isologous reactions, was described by Anderson, Goudie, and Gray (1960) in an investigation of precipitating antibody to thyroglobulin, and was also encountered in the present investigation, in which the tissue extracts of a patient whose serum contained anti-SjD not only failed to react with anti-SjD serum, but actually contained free anti$\mathrm{SjD}$ : this patient's tissue extracts reacted with anti-SjT and anti-Lup, thus providing a parallel to the negative autologous AICF tests. It seems clear that in this instance the antigen $\mathrm{SjD}$ was annulled, possibly during homogenization of the tissues, by anti-SjD present in the blood contained in them. In view of the evidence, referred to above, that several antigen-antibody systems participate in AICF reactions, the same explanation is applicable to the negative autologous AICF tests described by Mackay and Larkin (1959), and explains why these were encountered especially when the serum antibody titre was high.

Advantages and Disadvantages of the Precipitin Test.-This investigation has revealed both advantages and disadvantages in the use of the precipitin reaction to demonstrate the various antibodies reacting with tissue constituents in the serum of patients with connective tissue diseases. The precipitin reaction has three main advantages: it is readily applicable to the comparison of antibodies, both directly and by antigen-annulment; it provides opportunity to isolate antigenic constituents, by specific precipitation, from crude tissue extracts; it detects antibodies (e.g. anti-SjD) which may not be demonstrable by other methods.

The main disadvantage of the method is that it does not detect all the antibodies known to occur. It does not, for example, detect the antibody to DNP, which is usually present in the serum in active S.L.E. and is probably the abnormal serum factor responsible for the L.E.-cell phenomenon: this failure may be due to peculiarities of the antibody concerned or to poor diffusibility of DNP in agar.

There are several reports of the formation of non-immunological precipitates in agar-diffusion tests with serum and tissue extracts. In some of these, haemoglobin present in the tissue extract reacted to produce a precipitate with serum albumin (Leonardi, Zerbinato, and Andolfatto-Zaglia, 1956; Tomasi, 1961; Metzgar and Grace, 1961; Wilson and Warren, 1962) or with an $\alpha_{2}$-globulin (Peetoom, Rose, Ruddy, Micheli, and Grabar, 1960). We did not encounter these reactions in the present investigation, and preliminary experiments indicate that they are inhibited by the presence of sodium azide in the agar. The precipitation reaction described by Korngold, van Leeuwen, and Miller (1959) is unlikely to be concerned in the present investigation, for it required the use of dialysed serum.

The demonstration of multiple precipitating autoantibodies in patients with connective tissue diseases. 
provides further evidence of a profound immunological disturbance in these conditions. The observed incidence of the four types of antibody (Table I) suggests that there is some association between particular types of connective tissue disease and individual types of antibody. Thus, anti-SjD and anti-SjT were relatively common in Sjögren's disease and were the only antibodies identified in this condition: anti-Lup was found only in S.L.E. and progressive systemic sclerosis. Anti-SjD was widely distributed in the various connective tissue diseases, and thus provides a further association between members of the group.

Positive Precipitin Tests in Other Diseases.-The detection of anti-SjT in the two patients with "paraglobulinaemia" suggests that they may share the immunological disturbance of the connective tissue diseases. No firm conclusions can be drawn from the detection, in some of the control specimens, of unidentified precipitating factors, as evidence has not been provided that these are auto-antibodies. It is of interest, however, that three of the positive control specimens came from patients with severe chronic thyroiditis, two of whom also had hepatomegaly. Many of the specimens tested in the present investigation were examined also for antibody to thyroglobulin, and the incidence was found to be increased in groups of patients with S.L.E., Sjögren's disease, and rheumatoid arthritis (Anderson and others, 1961a). Similarly, Hijmans, Doniach, Roitt, and Holborow (1961) demonstrated an increased incidence of thyroid antibodies in S.L.E. These findings indicate the existence of an overlap between the organ-specific auto-immunity of chronic thyroiditis and the non-organ-specific auto-immune phenomena which characterize the connective tissue diseases.

\section{Summary}

Specimens of serum from 188 patients with connective tissue diseases and from 353 "control" patients were examined by an agar-diffusion technique for the presence of factors reacting to give precipitation with saline extracts of various human tissues. Precipitation was observed with 57 of the test serum specimens and with eight of the controls. The precipitating titres of positive specimens ranged up to 1 in 512. Comparative tests upon the positive specimens showed the occurrence among them of several precipitating factors. Four of these were investigated further, and evidence is presented that they are auto-antibodies which react with normal cellular constituents. One of the four cellular constituents concerned is considered to be deoxyribonucleic acid (DNA); the other three remain unidentified. The incidence of the four antibodies provides further links between the various types of connective tissue disease. At the same time, indivio dual connective tissue diseases tend to be associated. with particular antibodies.

Precipitating factors were detected in the serur of "control" patients with "paraglobulinaemia't chronic thyroiditis, liver disease, aplastic anaemia and sarcoidosis.

The results of precipitin tests are compared witb those described by workers using Gadjusek's "auto-immune complement-fixation reaction". (AICF), and an explanation of negative autologous tests reported with this latter technique is suggesteds

We wish to thank Dr. P. A. Charlwood for performing ultracentrifugal fractionation of serum, Dr. H. M. Keî for the highly purified DNA preparation, and Dr. $D_{f}$ Marrack for serum from cases of orbital pseudotumouru

The costs of this investigation was partly met by the research funds of Glasgow University, and by a grang from the Department of Health for Scotland.

\section{REFERENCES}

Ackroyd, J. F. (1955). Brit. med. Bull., 11, 28.

Anderson, J. R., Goudie, R. B., and Gray, K. G. (1960). Brit. J. exp. Path., 41, 364.

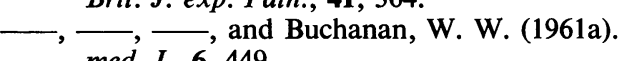
med. J., 6, 449. —, Gray, K. G., Beck, J. S., and Kinnear, W.

Asherson, G. L. (1959). Brit. J. exp. Path., 40, 209.

Beck, J. S. (1961). Lancet, 1, 1203.

Bunim, J. J. (1961). Ann. rheum. Dis., 20, 1.

Ceppellini, R., Polli, E., and Celada, F. (1957). Proc Soc. exp. Biol. (N.Y.), 96, 572.

Crampton, C. F., Lipshitz, R., and Chargaff, E. (1954)? J. biol. Chem., 206, 499.

Deicher, H. R. G., Holman, H. R., and Kunkel, H. G. (1959). J. exp. Med., 109, 97.

,--1 (1960). Arthr. and Rheum., 3, 1.

,,,--- , and Ovary, Z. (1960). J. Immunol. 84, 106.

Gajdusek, D. C. (1957). Nature (Lond.), 179, 666.

(1958). Arch. intern. Med., 101, 9.

Hackett, E., Beech, M., and Forbes, I. J. (1960). Brito med. J., $2,17$.

Heaton, J. M. (1959). Ibid., 1, 466.

Hijmans, W., Doniach, D., Roitt, I. M., and Holborow E. J. (1961). Ibid., 2, 909.

Holborow, E. J., and Weir, D. M. (1959). Lancet, $1,809$.

Holman, H. R., and Deicher, H. R. G. (1959). J. clin N

- Invest., 38, 2059. and Kunkel, H. G. (1959). Bull. N. Y. Acad. Med., 35, 409.

Kaiser, I. H. (1942). Bull. Johns Hopk. Hosp., 71, 31. Kay, E. R. M., Simmons, N. S., and Dounce, A. L? (1952). J. Amer. chem. Soc., 74, 1724. 
Korngold, L., and van Leeuwen, G. (1959). Int. Arch. Allergy, 15, 278.

, - and Miller, D. G. (1959). Nature (Lond.), $183,330$.

Lachmann, P. J., and Kunkel, H. G. (1961). Lancet, 2, 436.

Leonardi, P., Zerbinato, A., and Andolfatto-Zaglia, G. (1956). Boll. Ist. sieroter. milan., 35, 613.

Mackay, I. R., and Gajdusek, D. C. (1958). Arch. intern. Med., 101, 30.

- , and Larkin, L. (1959). Clin. Sci., 18, 425.

Metzgar, R. S., and Grace, J. T., Jr. (1961). J. Immunol., 86, 578.

Miescher, P., and Strässle, R. (1957). Vox sang. (Basel), n.s. 2, 283.

Mirsky, A. E., and Pollister, A. W. (1946). J. gen. Physiol., 30, 117.

Pearson, C. M., Craddock, C. G., and Simmons, N. S. (1958). J. Lab. clin. Med., 52, 580.

Peetoom, F., Rose, N., Ruddy, S., Micheli, A., and Grabar, P. (1960). Ann. Inst. Pasteur, 98, 252.

Robbins, W. C., Holman, H. R., Deicher, H. R. G., and Kunkel, H. G. (1957). Proc. Soc. exp. Biol. (N.Y.), 96, 575.

Seligmann, M. (1957). C.R. Acad. Sci., 245, 243.

(1958). Rev. franç. Étud. clin. biol., 3, 558.

Tomasi, T. B. (1961). J. Immunol., 86, 427.

Wilson, J. F., and Warren, G. (1962). J. clin. Path., $15,40$.

\section{Auto-anticorps précipitants dans les maladies du tissu conjonctif}

\section{RÉSUMÉ}

Des échantillons du sérum de $\mathbf{1 8 8}$ malades atteints de maladies du tissu conjonctif et de 353 témoins furent éxaminés par un procédé de diffusion sur agar pour décéler la présence des facteurs réagissant par précipitation avec des extraits salins de divers tissus humains. Un précipité fut observé avec 57 échantillons des malades étudiés et avec 8 échantillons témoins. Les titres de précipitation des échantillons positifs allaient jusqu'à 1/512. Des tests comparés sur des échantillons positifs y montrèrent l'existence de plusieurs facteurs précipitants. On procéda à une étude plus approfondie de quatre de ces facteurs et on trouva des données indiquant qu'il s'agit d'auto-anticorps réagissant avec des composants cellulaires normaux. On considère qu'un des quatre composants cellulaires impliqués est l'acide deoxyribonucléique (DNA); les trois autres restent à identifier. L'occurrence des quatre anticorps montre une fois de plus l'existence des liens entre les différents types de la maladie du tissu conjonctif. En même temps, les maladies du tissu conjonctif individuelles tendent à être associées aux anticorps particuliers.

Des facteurs précipitants furent décélés dans le sérum des témoins, atteints de "paraglobulinémie", de thyroïdite chronique, d'affection hépatique, d'anémie aplastique et de sarcoïdose.

On compare les résultats de la réaction de précipitation à ceux décrits par des auteurs qui ont employé la "réaction auto-immune de fixation du complément" (AICF) de Gajdusek et on offre une explication des tests autologues négatifs rapportés avec ce procédé.

\section{Auto-anticuerpos precipitantes en las enfermedades del teijdo conectivo \\ Sumario}

Espécimenes del suero de 188 sujetos con enfermedades del tejido conectivo y de 353 testigos fueron examinados por un procedimiento de difusión sobre agar para revelar la presencia de factores que dan una reacción de precipitación con extractos salinos de varios tejidos humanos. Un precipitado fué observado con 57 espécimenes procedentes de enfermos estudiados y con 8 espécimenes testigos. Los títulos de precipitación de los espécimenes positivos iban hasta $1 / 512$. Reacciones de comparación con espécimenes positivos mostraron la presencia de varios factores precipitantes. Cuatro de estos factores fueron estudiados más detalladamente y se encontraron pruebas de que se trata de auto-anticuerpos que reaccionan con componentes celulares normales. Se considera que uno de los cuatro componentes celulares implicados es el ácido deoxiribonucleíco (DNA); la identidad de los demás tres no se conoce todavía. La incidencia de los cuatro anticuerpos demuestra una vez más la existencia de conexiones entre diferentes tipos de la enfermedad del tejido conectivo. Al mismo tiempo, las enfermedades individuales del tejido conectivo tienden a asociarse con anticuerpos particulares.

Factores precipitantes fueron encontrados en el suero de los testigos afectos de "paraglobulinemia", tiroiditis crónica, enfermedad hepática, anemia aplástica y sarcoidosis.

Se comparan los resultados de la reacción de precipitación con los descritos por autores que habían empleado la "reacción auto-inmune de fijación del complemento" (AICF) de Gajdusek y se ofrece una explicación de los tests autólogos negativos relatados con este método. 